\title{
SO2 Oxidation Across Marine V2O5-WO3-TiO2 SCR Catalysts: a Study at Elevated Pressure for Preturbine SCR Configuration
}

Christensen, Steen R.; Hansen, Brian B.; Johansen, Keld; Pedersen, Kim H.; Thøgersen, Joakim R.; Jensen, Anker Degn

\section{Published in:}

Emission Control Science and Technology

Link to article, DOI:

$10.1007 / \mathrm{s} 40825-018-0092-8$

Publication date:

2018

Document Version

Peer reviewed version

Link back to DTU Orbit

Citation $(A P A)$ :

Christensen, S. R., Hansen, B. B., Johansen, K., Pedersen, K. H., Thøgersen, J. R., \& Jensen, A. D. (2018). $\mathrm{SO}_{3}$ Oxidation Across Marine $\mathrm{V}_{2} \mathrm{O}_{-}-\mathrm{WO}_{3}-\mathrm{TiO}$, SCR Catalysts: a Study at Elevated Pressure for Preturbine SCR Configuration. Emission CZntrol Science and Technology, 4, 289-299. https://doi.org/10.1007/s40825-0180092-8

\section{General rights}

Copyright and moral rights for the publications made accessible in the public portal are retained by the authors and/or other copyright owners and it is a condition of accessing publications that users recognise and abide by the legal requirements associated with these rights.

- Users may download and print one copy of any publication from the public portal for the purpose of private study or research.

- You may not further distribute the material or use it for any profit-making activity or commercial gain

- You may freely distribute the URL identifying the publication in the public portal 


\title{
$\mathrm{SO}_{2}$ Oxidation across Marine $\mathrm{V}_{2} \mathrm{O}_{5}-\mathrm{WO}_{3}-\mathrm{TiO}_{2}$ SCR Catalysts - A Study at Elevated Pressure for Preturbine SCR Configuration
}

\author{
Steen R. Christensen ${ }^{a}$, Brian B. Hansen ${ }^{a}$, Keld Johansen ${ }^{b}$, Kim H. Pedersen ${ }^{c}$, Joakim R. \\ Thøgersen ${ }^{c}$, Anker Degn Jensen ${ }^{\mathrm{a}, *}$ \\ ${ }^{a}$ Department of Chemical and Biochemical Engineering, Technical University of Denmark, \\ Søltofts Plads B229, 2800 Kgs Lyngby, Denmark \\ ${ }^{b}$ Haldor Topsoe A/S, Haldor Topsøes Allé 1, 2800 Kgs. Lyngby, Denmark \\ 'Umicore Denmark ApS, Nøjsomhedsvej 20, DK-2800 Kgs. Lyngby, Denmark \\ *Corresponding author: aj@kt.dtu.dk ,+45 4525 2841, OrCID: 0000-0002-7341-4859
}

\begin{abstract}
The undesired oxidation of $\mathrm{SO}_{2}$ was studied experimentally at elevated pressures of up to $4.5 \mathrm{bar}$ across two commercial vanadium ( $1.2 \mathrm{wt} \%$ and $3 \mathrm{wt} \% \mathrm{~V}_{2} \mathrm{O}_{5}$ ) based Selective Catalytic Reduction (SCR) catalysts. This pressure range, is of interest for preturbine SCR reactor configuration for $\mathrm{NO}_{x}$ reduction on ships. The residence time in the catalyst was kept constant, independent on pressure, by adjusting the total flow rate. The conversion of $\mathrm{SO}_{2}$ was of the order $0.2-3 \%$ at temperatures of $300-400^{\circ} \mathrm{C}$ and was independent of the pressure. Based on the measured conversion of $\mathrm{SO}_{2}$, the kinetics were fitted using a $\mathrm{n}^{\prime}$ th order rate expression. The reaction order of $\mathrm{SO}_{2}$ was found close to one, and the reaction order of $\mathrm{SO}_{3}$ was found close to zero, also at increased pressures of up to 4.5 bar. The rate of $\mathrm{SO}_{2}$ oxidation was clearly promoted by the presence of 1000 ppm NO at elevated pressure, however, at atmospheric pressure the effect was within experimental uncertainty. The promoting effect is explained by a catalyzed redox reaction between $\mathrm{SO}_{2}$ and $\mathrm{NO}_{2}$, and since more $\mathrm{NO}_{2}$ is formed at elevated pressure, a higher degree of promotion by $\mathrm{NO}_{x}$ is observed at elevated pressures.
\end{abstract}

\section{Keywords}

SO2 oxidation; Pressurized SO2 oxidation; preturbo SCR configuration; SCR of NOx on Ships; SO3 formation; 


\section{Introduction}

In today's shipping industry, more than $90 \%$ of oceangoing vessels are powered by diesel engines burning fossil fuels ${ }^{1}$. Emissions, such as nitrogen oxides $\left(\mathrm{NO}_{\mathrm{x}}\right)$ and sulfur oxides $\left(\mathrm{SO}_{\mathrm{x}}\right)$ contributes to the acidification of the sea and land and also reduced air quality in harbor cities ${ }^{2}$. Around $70 \%$ of the emissions from ships are produced within $400 \mathrm{~km}$. of land, and the shipping industry contributes to approximately $15 \%$ of the global anthropogenic $\mathrm{NO}_{\mathrm{x}}$ and $5-8 \%$ of the global $\mathrm{SO}_{\mathrm{x}}$ emissions ${ }^{3,4}$. Consequently, limitations of $\mathrm{NO}_{\mathrm{x}}$ and $\mathrm{SO}_{\mathrm{x}}$ emissions are targeted through the introduction of Marpol 73/78 Annex VI Tier III regulation 13 and $14^{5}$.

The new Tier III, regulation 13, is an approximate $75 \% \mathrm{NO}_{x}$ reduction, compared to the earlier IMO Tier II regulation (Jan. 2011) as shown in Fig. 1. Tier III compliance is required for all ships built after 1 . January 2016 when sailing within $\mathrm{NO}_{\mathrm{x}}$ Emission Control Areas (NECA's), such as the Baltic Sea or in the North Sea ${ }^{5}$. Marpol 73/78 regulation 14 states the maximum allowed sulfur content in the fuel onboard a ship which depends on whether the ship is operated in- or outside of a $\mathrm{SO}_{\mathrm{x}}$ Emission Control Area (SECA). Regulation 14 requires maximum $0.1 \mathrm{wt} \% \mathrm{~S}$ within SECA's but also states that a higher sulfur content is allowed, as long as the sulfur emissions are reduced to at least the same extent as if a low sulfur fuel was used ${ }^{5}$.

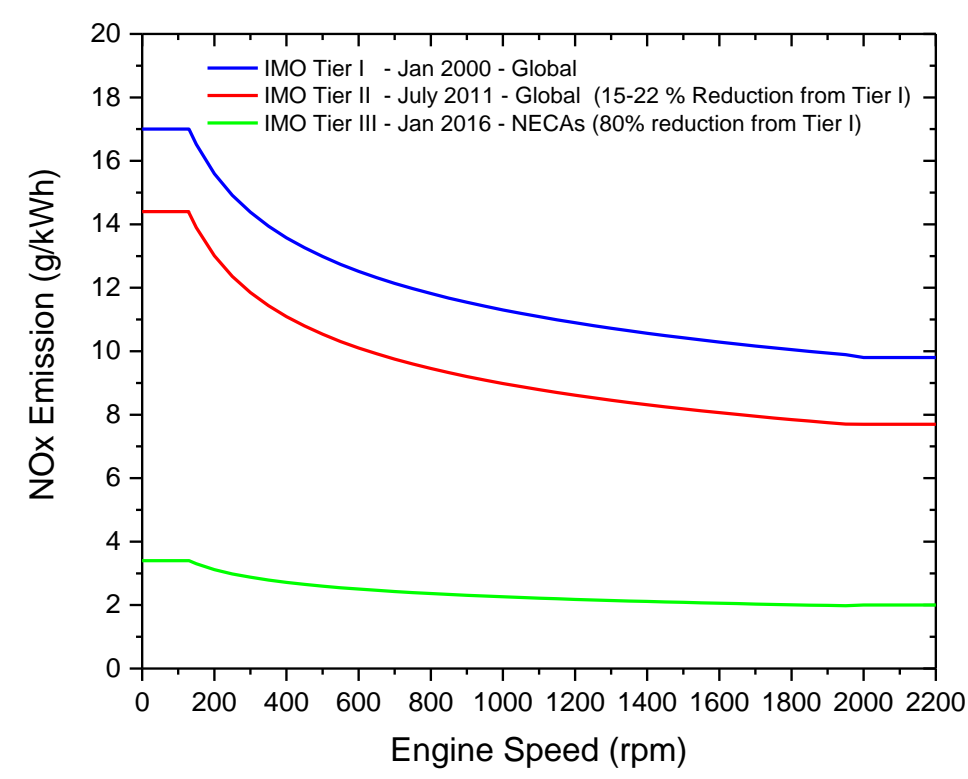

Fig. 1 Allowed NOx emissions as a function of engine speed according to Marpol 73/78 Annex VI Regulation $13^{5}$

The $\mathrm{NO}_{\mathrm{x}}$ compliance to IMO Tier III is expected to be achieved through either Exhaust Gas Recirculation (EGR), use of dual-fuel engines, or by the implementation of Selective 
Catalytic Reduction (SCR) of $\mathrm{NO}_{x}{ }^{6}$. EGR is a primary $\mathrm{NO}_{x}$ reduction method, in which the production of $\mathrm{NO}_{x}$ from the engine is reduced by lowering the combustion temperature and oxygen content through recirculation of exhaust gas (increased $\mathrm{H}_{2} \mathrm{O}$ and $\mathrm{CO}_{2}$ inside the combustion chamber $)^{1} . \mathrm{SCR}$, on the other hand, is a secondary $\mathrm{NO}_{\mathrm{x}}$ reduction method, in which the $\mathrm{NO}_{\mathrm{x}}$ emissions are reduced downstream of the engine, by introducing a catalytic reactor in the exhaust gas aftertreatment system.

SCR of $\mathrm{NO}_{x}$ is a well-known technology, which has been used on both stationary and mobile sources to reduce $\mathrm{NO}_{x}$ emissions since the $1980 \mathrm{~s}^{7-9}$. $\mathrm{NO}_{x}$ emissions from mobile units, such as ships, are reduced across a catalyst by introducing a $30-40 \mathrm{wt} \%$ aqueous solution of urea usually sprayed into the exhaust gas as small droplets upstream of the catalyst ${ }^{10}$. The droplets evaporate and decompose into ammonia and $\mathrm{CO}_{2}$ according to reaction (1). Ammonia then reacts with oxygen and $\mathrm{NO}_{\mathrm{x}}$ across the catalyst forming harmless nitrogen and water, according to reaction (2) resulting in a $\mathrm{NO}_{\mathrm{x}}$ reduction of usually $80-95 \%$ at temperatures of $300-450{ }^{\circ} \mathrm{C}^{10}$.

$$
\begin{aligned}
& \mathrm{NH}_{2}-\mathrm{CO}-\mathrm{NH}_{2}+\mathrm{H}_{2} \mathrm{O} \rightarrow 2 \mathrm{NH}_{3}+\mathrm{CO}_{2} \\
& 4 \mathrm{NH}_{3}+4 \mathrm{NO}+\mathrm{O}_{2} \rightarrow 4 \mathrm{~N}_{2}+6 \mathrm{H}_{2} \mathrm{O}
\end{aligned}
$$

The catalyst used for SCR of $\mathrm{NO}_{x}$ on ships is usually the ternary vanadium based (V-SCR) catalyst, doped with tungsten on a carrier of titanium dioxide $\left(\mathrm{V}_{2} \mathrm{O}_{5} / \mathrm{WO}_{3} / \mathrm{TiO}_{2}\right)^{11-13}$. The V-SCR catalysts are well known for not being deactivated by the high $\mathrm{SO}_{2}$ concentrations, up to $1000 \mathrm{ppm}$, present in marine diesel exhaust gas ${ }^{14-16}$. The oxidation of $\mathrm{SO}_{2}$ according to reaction (3), is also slightly activated by a V-SCR catalyst, usually resulting in an $\mathrm{SO}_{2}$ oxidation of $1-3 \%$ under SCR operating conditions ${ }^{17}$. This reaction is critical to study because the produced $\mathrm{SO}_{3}$ readily reacts with water forming sulfuric acid causing corrosion, or it can further react with ammonia forming ammonium bisulfate (ABS) or ammonium sulfate (AS) according to reaction (4) and (5) respectively ${ }^{18-20}$.

$$
\begin{gathered}
\mathrm{SO}_{2}+1 / 2 \mathrm{O}_{2} \rightarrow \mathrm{SO}_{3} \\
\mathrm{SO}_{3}+\mathrm{H}_{2} \mathrm{O}+\mathrm{NH}_{3} \rightarrow \mathrm{NH}_{4} \mathrm{HSO}_{4} \\
\mathrm{SO}_{3}+\mathrm{H}_{2} \mathrm{O}+2 \mathrm{NH}_{3} \rightarrow\left(\mathrm{NH}_{4}\right)_{2} \mathrm{SO}_{4}
\end{gathered}
$$


The formed sulfates may condense when the exhaust gas temperature decreases. The condensation of sulfates within the catalyst pore system is a particular problem, since capillary forces result in a higher dew point temperature than in the bulk, and therefore a higher temperature is needed to ensure that the catalyst is not deactivated ${ }^{20,21}$. The specific dew point temperature depends on both the concentrations of $\mathrm{NH}_{3}, \mathrm{H}_{2} \mathrm{SO}_{4}$, and the pore sizes ${ }^{20}$. With a high sulfur fuel (e.g., 3.5 wt\% sulfur) the catalyst must, therefore, be placed at temperatures above $330-340^{\circ} \mathrm{C}^{11,22}$. However, if a low sulfur fuel is used instead (e.g., 0.1 wt\% of sulfur) a lower temperature of $260^{\circ} \mathrm{C}$ can be used, without deactivating the catalyst ${ }^{22}$. In two-stroke marine diesel engines such high temperatures are only continuously achievable by installing the catalytic reactor upstream of the turbocharger, where a pressure of up to 4.5 bar is present ${ }^{11}$. The higher pressure will increase the condensation temperature ${ }^{23}$ and could affect the oxidation of $\mathrm{SO}_{2}$.

Earlier studies of $\mathrm{SO}_{2}$ oxidation ${ }^{24-26}$ have reported that the rate of $\mathrm{SO}_{2}$ oxidation has a zero order oxygen dependency at concentrations above 1-2 vol\%, which is the case for marine diesel engines exhaust gas $\left(\mathrm{O}_{2}>10\right.$ vol\% $\left.{ }^{1,27}\right)$. Water has been reported to inhibit the rate of $\mathrm{SO}_{2}$ oxidation ${ }^{25}$, however, at practical water concentrations $(5-15 \%)$ the rate is found to be independent of the water concentration. The reaction is commonly reported to be first order in $\mathrm{SO}_{2}{ }^{28-30}$, while the reported $\mathrm{SO}_{3}$ orders range from negative first $\operatorname{order}^{24}$ to a zero order dependency ${ }^{28-30}$. Earlier studies have all been carried out at atmospheric pressure. Therefore this study will expand upon the current knowledge of catalytic $\mathrm{SO}_{2}$ oxidation to high pressure marine conditions, using two commercial $\mathrm{V}_{2} \mathrm{O}_{5} / \mathrm{WO}_{3} / \mathrm{TiO}_{2}$ catalysts supplied by Haldor Topsøe A/S. The effect of temperature, pressure, $\mathrm{SO}_{2}$ concentration, and $\mathrm{NO}_{x}$ concentration is presented.

\section{Experimental Methods}

\subsection{Apparatus}

The setup used for measurements of pressurized $\mathrm{SO}_{2}$ oxidation is shown schematically in Fig. 2. Nitrogen, air, and liquid water were added to the first heater (HE1) using Brooks Smart Mass Flow Controllers (MFC's) for gas addition and Brooks liquid mass Flow model 5882 for addition of water. Water was evaporated in the first heater, a second heater (HE2) was used to control the reaction temperature in the range of $290-420{ }^{\circ} \mathrm{C}$, and heating elements around the reactor helped to maintain the reaction temperature. A 
manual backpressure valve was used to control the reaction pressure to between 1-4.5 bar. Gaseous $\mathrm{SO}_{2}$ was added to the hot gas and passed through a static mixer from Sulzer, before reaching the reactor. The standard experimental conditions were: $5 \%$ $\mathrm{H}_{2} \mathrm{O}, 8-10 \% \mathrm{O}_{2}$, and approximately 1000 ppm of $\mathrm{SO}_{2}$ in $\mathrm{N}_{2}$ as shown in Table 1, and in some experiments, $1000-1500 \mathrm{ppm}$ of $\mathrm{NO}_{\mathrm{x}}$ was also added to the flue gas before the mixer, as with $\mathrm{SO}_{2}$. Isothermal conditions were verified by K-type thermocouples placed before and after the catalyst.

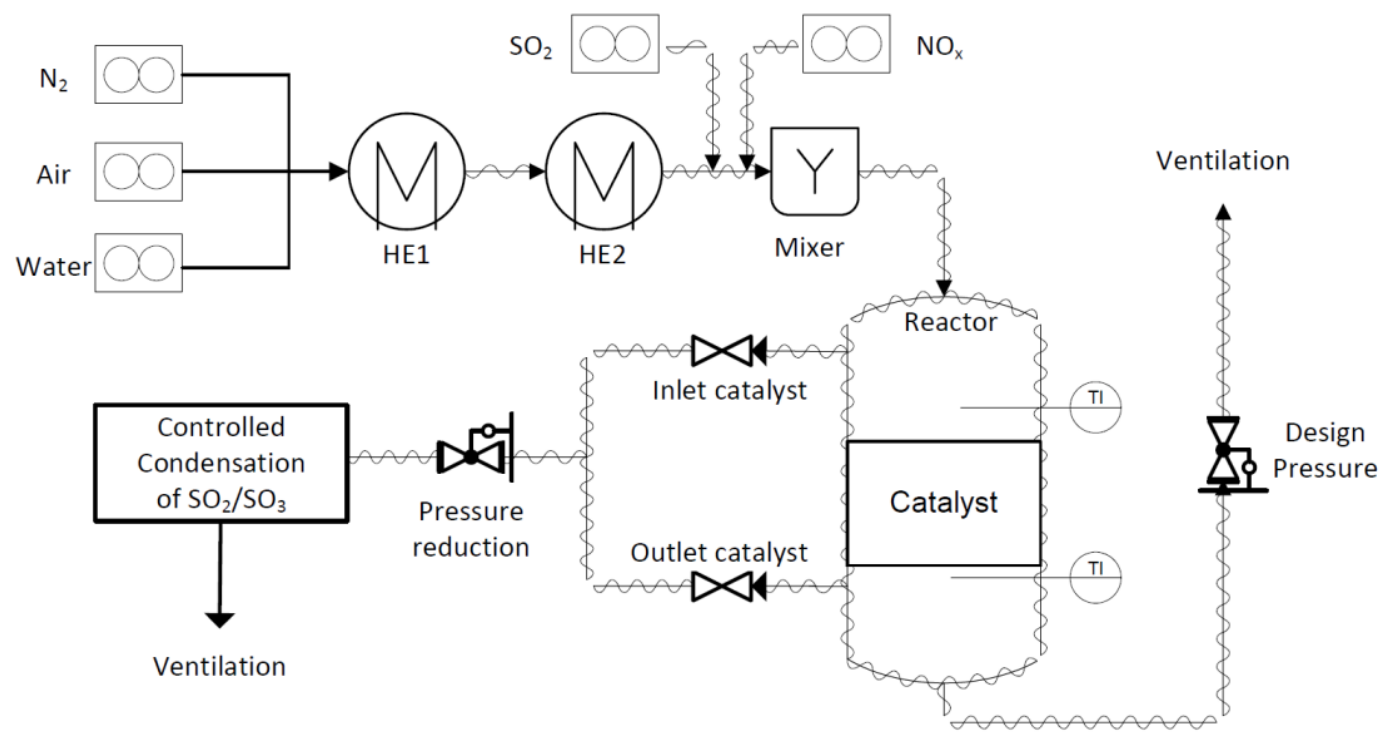

Fig. 2 Monolith reactor setup at Haldor Topsøe A/S

To reach steady state conditions, a conditioning period of $15-20 \mathrm{~h}$ must be used when measuring the oxidation of $\mathrm{SO}_{2}$. The long conditioning time is due to sulfating of the catalyst and is part of the mechanism behind $\mathrm{SO}_{2}$ oxidation, involving adsorption of $\mathrm{SO}_{2}$, oxidation of $\mathrm{SO}_{2}$ to $\mathrm{SO}_{3}$ on the surface of the catalyst, and lastly the desorption of $\mathrm{SO}_{3}$ 17,25,30. To ensure sufficient conditioning time, the catalyst was left overnight after a change in temperature, species concentration, or pressure was introduced. Sufficient conditioning time was assumed when two measurements, with approximately 2-4 hours between each measurement, using the same conditions showed the same conversion of $\mathrm{SO}_{2}$. If this was not the case, the catalyst was left an additional day, and measurements were repeated.

Table 1 gives an overview of the performed experiments covering 2 different commercial maritime SCR catalysts. To clarify the direct pressure effects on reaction kinetics, similar residence times in the catalyst were imposed by increasing the total flow rate proportionally to the pressure. The residence time for the different conditions 
is indicated by the linear velocity through the channels or by the weight based residence time $(W / Q)$, where $W$ is the mass of the catalyst element and $Q$ is the total volumetric flow rate (1 bar, 0 C), as shown in Table 1. As shown in Table 1 there were minor changes in the $\mathrm{SO}_{2}$ inlet concentration when the pressure was varied, indicating offset in the actual total flow compared to the expected total flow. The total flow rate as shown in Table 1, was therefore calculated from the measured outlet $\mathrm{SO}_{x}$ concentrations and the flow rate of $\mathrm{SO}_{2}$ added to the flue gas.

Table 1 The total flow rate and the linear velocity through the catalyst channels (at reaction pressure and $0{ }^{\circ} \mathrm{C}$ ). The measured mean inlet concentration and the standard deviation based upon all measurements are also shown

\begin{tabular}{|c|c|c|c|c|c|}
\hline Catalyst & Pressure & Total Flow rate & $\begin{array}{l}\text { Linear } \\
\text { Velocity }\end{array}$ & $\frac{\text { Mean } \mathrm{SO}_{2}}{\text { Conc. }}$ Inlet & $\begin{array}{l}\text { Weight Based } \\
\text { Residence time }\end{array}$ \\
\hline & Bar & $\begin{array}{c}\mathrm{m}^{3} / \mathrm{h} @ 0{ }^{\circ} \mathrm{C}, 1 \\
\text { atm. }\end{array}$ & $\mathrm{m} / \mathrm{s} @ 0{ }^{\circ} \mathrm{C}$ & ppm, dry & $\mathrm{Kg}_{\text {cat }} \cdot \mathrm{s} / \mathrm{m}^{3}$ \\
\hline $\begin{array}{c}0.66 \text { L Low V- } \\
\text { SCR }\end{array}$ & 1 & 4.5 & 0.85 & $930 \pm 15$ & 119.1 \\
\hline $\begin{array}{c}0.66 \text { L Low V- } \\
\text { SCR }\end{array}$ & 3 & 14.4 & 0.94 & $860 \pm 15$ & 107.3 \\
\hline $\begin{array}{c}0.66 \text { L Low V- } \\
\text { SCR }\end{array}$ & 4.5 & 21.9 & 0.95 & $850 \pm 15$ & 106.0 \\
\hline $\begin{array}{c}0.34 \text { L High V- } \\
\text { SCR }\end{array}$ & 1 & 2.6 & 0.48 & $1120 \pm 15$ & 97.5 \\
\hline $\begin{array}{c}0.34 \text { L High V- } \\
\text { SCR }\end{array}$ & 2.9 & 8.5 & 0.55 & $980 \pm 15$ & 84.5 \\
\hline
\end{tabular}

The outlet concentrations of $\mathrm{SO}_{2}$ and $\mathrm{SO}_{3}$ were measured using the controlled condensation method as described by the Topsøe method $1305^{31}$, which is a modification of the ASTM D-3226-73T standard method. The Topsøe method is based on controlled condensation of sulfuric acid at a temperature of $70{ }^{\circ} \mathrm{C}$ and subsequent titration of sulfate ions. At a temperature of $70^{\circ} \mathrm{C}$ only sulfuric acid will condense, and since $\mathrm{SO}_{2}$ has a very low solubility in sulfuric acid, $\mathrm{SO}_{2}$ will be unaffected by the condensation. $\mathrm{SO}_{2}$ is then subsequently collected in a $6 \%$ aqueous solution of $\mathrm{H}_{2} \mathrm{O}_{2}$ (converted into sulfuric acid). The collected samples are titrated with $0.005 \mathrm{M}$ barium 
perchlorate as titrant and thorin as an indicator, using a Metrohm 862 compact titrosampler.

\subsection{Catalysts}

The conversion of $\mathrm{SO}_{2}$ into $\mathrm{SO}_{3}$ was measured for two ternary (1.2 wt\% or 3 wt\% $\mathrm{V}_{2} \mathrm{O}_{5}$ / $\sim 10 \% \mathrm{WO}_{3} / \mathrm{TiO}_{2}$ ) marine SCR catalyst (V-SCR) with a honeycomb structure supplied by Haldor Topsøe A/S. Both catalysts were cut into a square cross-sectional surface area $(43.5 \mathrm{~mm})$ to fit into the reactor and sealed with quartz wool as shown in Fig. 3.
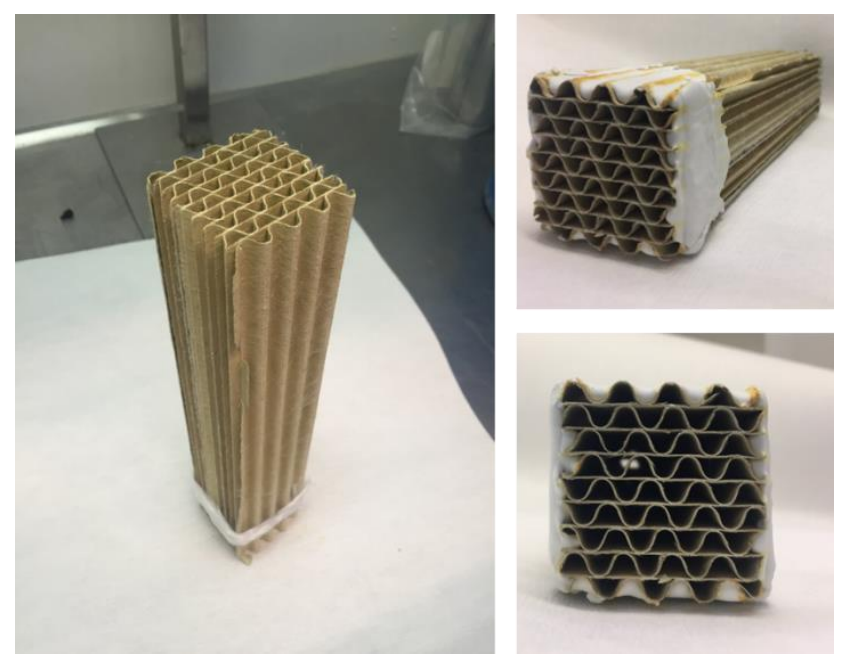

Fig. 3 Pictures of the high vanadia content SCR catalyst, with quartz wool in one end. It should be noted that the catalyst was fixed using quartz wool in both ends before loading

The catalyst was forced to fit into the reactor to ensure that no gas would bypass the catalyst. Further information on the catalyst properties can be found in Table 2. A roughly twice as large volume of catalyst was used for the low V-SCR catalyst to get a reasonable amount of $\mathrm{SO}_{2}$ oxidation also at the lowest temperature of $300{ }^{\circ} \mathrm{C}$.

Table 2 Characteristics of the tested catalysts

\begin{tabular}{lcc}
\hline & Low V-SCR & High V-SCR \\
\hline $\mathrm{V}_{2} \mathrm{O}_{5}$ Content $-\mathrm{wt} \%$ & 1.2 & 3 \\
Width or Length $-\mathrm{mm}$ & 43.6 & 43.5 \\
Height $-\mathrm{mm}$ & 460 & 231 \\
Weight $-\mathrm{g}$ & 145.7 & 69 \\
\# of open Channels & 59 & 61 \\
\hline
\end{tabular}




\begin{tabular}{lcc}
\hline Hydraulic diameter $-\mathrm{mm}$ & 4.3 & 4.3 \\
Void - \% & 80 & 80
\end{tabular}

\section{Results and Discussion}

\subsection{Pressurized $\mathrm{SO}_{2}$ Oxidation}

A background measurement was performed at $390^{\circ} \mathrm{C}, 1000 \mathrm{ppm} \mathrm{SO}$, and 1 bar, by measuring the conversion of $\mathrm{SO}_{2}$ at the inlet to the catalyst, which yielded a negligible $\mathrm{SO}_{2}$ oxidation (0.07\%). Consequently, the conversion of $\mathrm{SO}_{2}$ into $\mathrm{SO}_{3}$ could be measured by simultaneously measuring the $\mathrm{SO}_{2}$ and $\mathrm{SO}_{3}$ concentration out of the reactor. The sum of $\mathrm{SO}_{2}$ and $\mathrm{SO}_{3}$ out of the reactor was assumed to correspond to the inlet concentration of $\mathrm{SO}_{2}$. The conversion of $\mathrm{SO}_{2}$ was calculated based on the measured $\mathrm{SO}_{3}$ concentration and the inlet concentration of $\mathrm{SO}_{2}$.

The conversion of $\mathrm{SO}_{2}$ was measured across a low V-SCR and a high V-SCR catalyst at temperatures and pressures relevant for marine $S C R$, i.e., $300-400^{\circ} \mathrm{C}$ and $1-4.5$ bar and the results are shown in Fig. 4. The mean conversion of $\mathrm{SO}_{2}$ is shown by the symbols in Fig 4 and is based upon two measurements. The two measurements used to calculate the mean are shown as the top and bottom point of the bar in each symbol.

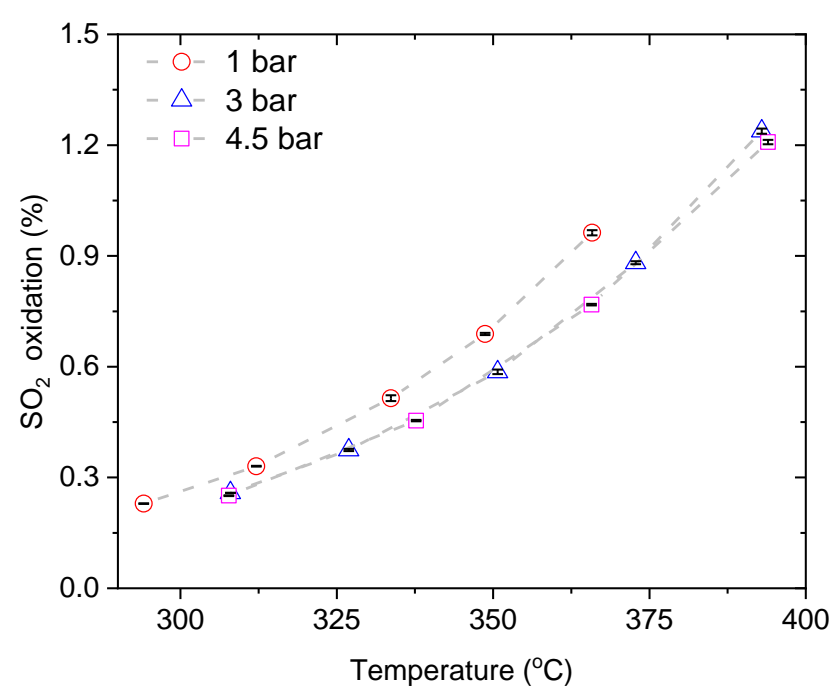

Fig. 4(a) Conversion of $\mathrm{SO}_{2}$ for the Low V-SCR catalyst 


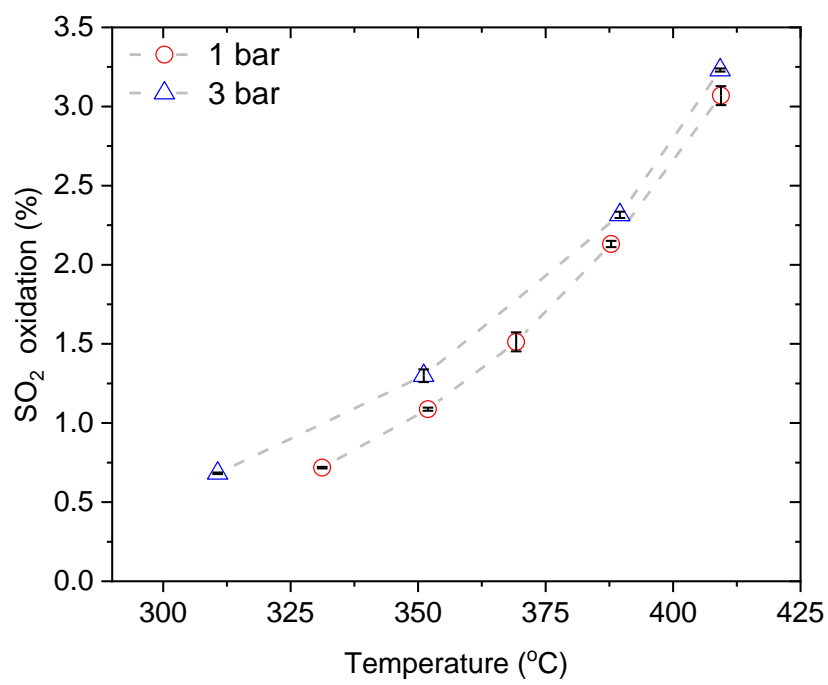

Fig. 4(b) Conversion of $\mathrm{SO}_{2}$ for the High V-SCR catalyst

Fig. 4 The mean steady state $\mathrm{SO}_{2}$ oxidation measured across two marine type commercial V-SCR catalysts. Symbols shows the mean, top and bottom of bar is the two measurements used to calculate the mean, and dashed lines connects each measurement. General test conditions were $5 \% \mathrm{H}_{2} \mathrm{O}, 8-10 \% \mathrm{O}_{2}, \mathrm{SO}_{2}$ according to Table 1 and balance $\mathrm{N}_{2}$. It should be noted that the 3 bar test for the high V-SCR was performed with $2 \% \mathrm{H}_{2} \mathrm{O}$ as discussed in Section 3.2

Fig. 4 shows that when the residence time is kept constant, as is the case for 3 and 4.5 bar for the low V-SCR catalyst, according to Table 1, the measured conversion of $\mathrm{SO}_{2}$ is identical, independent of the change in pressure, indicating pressure independent kinetics. Fig. 4 shows that in general a higher conversion of $\mathrm{SO}_{2}$ is found for the high $\mathrm{V}$ SCR catalyst compared to the low V-SCR catalyst as has also been found in literature ${ }^{24,28}$. The highest measured conversion of $\mathrm{SO}_{2}$ is below approximately $1.2 \%$ for the low $\mathrm{V}-\mathrm{SCR}$ catalyst (Figure $4 \mathrm{a}$ ) and $3.2 \%$ for the high V-SCR catalyst (Figure 4b). For the high V-SCR

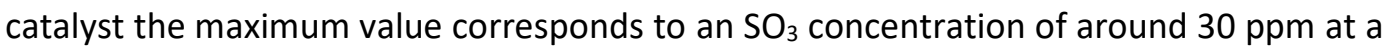
pressure of 3 bar. It should be noted that these levels of $\mathrm{SO}_{2}$ conversion are far below the equilibrium conversion predicted by HSC chemistry $9.0^{\circledR}\left(X_{e}\left(300-400^{\circ} \mathrm{C}\right) \gg\right.$ 95\%) and therefore, the measured kinetics are not influenced by the reverse reaction. A similar conversion of $\mathrm{SO}_{2}$ has also been reported by other authors in studies at atmospheric pressure ${ }^{8,17,32}$. The two measurements performed at each steady state, as indicated by the top and bottom of the bars in each symbol shows that the double determination gave very similar results for the low V-SCR catalyst, indicating steady state conditions and good repeatability. For the high V-SCR catalyst (Fig. 4b) a higher uncertainty, compared to the low V-SCR catalyst, is observed. The measured conversion of $\mathrm{SO}_{2}$ at the high V-SCR catalyst is higher at 3 bar, even though the residence time in 
the catalyst is lower (by 12\%) than the residence time at 1 bar, as also shown in Table 1 , which is unexpected and must be due to uncertainties in the calculated/measured flow. The observed uncertainty is not considered prohibitively large and the results are useful and trustworthy.

\section{2 $\mathrm{SO}_{2}$ Oxidation and $\mathrm{H}_{2} \mathrm{O}$}

Addition of water significantly decreases the $\mathrm{SO}_{2}$ oxidation, but at practical water concentrations ( $\geq 5$ vol\% at atmospheric pressure) the rate of $\mathrm{SO}_{2}$ oxidation is known to be independent of the water concentration ${ }^{8,25}$. Therefore, experiments were in general performed with 5 vol\% of water in the gas, however, MFC limitations during the 3 bar high V-SCR experiment yielded only 2 vol\% of water. A repetition was, therefore, performed at $390^{\circ} \mathrm{C}$ and 3 bar, both with 2 vol\% of water and 5 vol\% of water in the gas to ensure that the results obtained with 2 vol\% of water at 3 bar could be compared to the results using 5 vol\% of water at 1 bar. Fig. 5 shows the measured conversion of $\mathrm{SO}_{2}$.

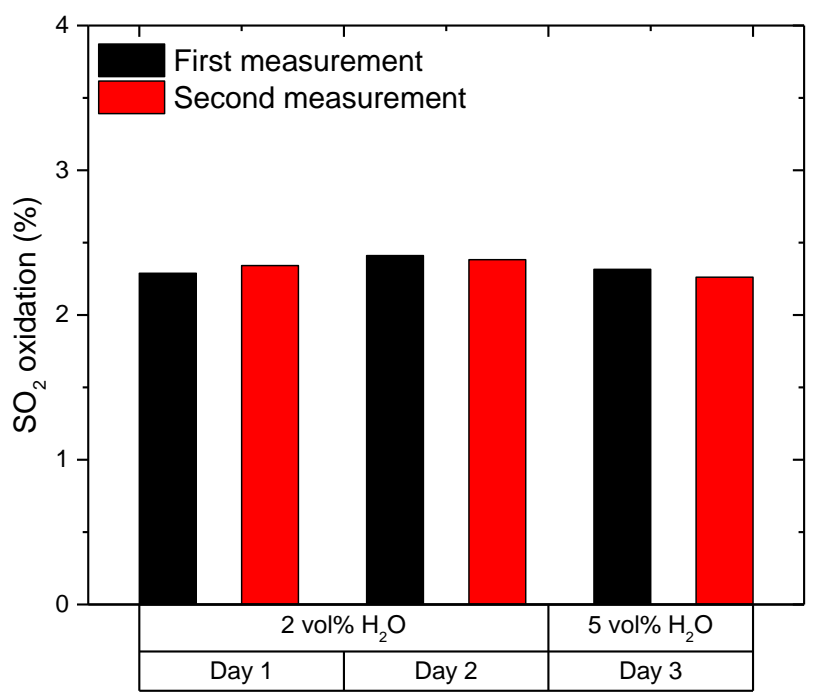

Fig. 5 Repetition of $\mathrm{SO}_{2}$ oxidation at $390^{\circ} \mathrm{C}$ and 3 bar across the high V-SCR with 2 vol\% and 5 vol\% of $\mathrm{H}_{2} \mathrm{O}$

Fig. 5 shows that at a temperature of $390^{\circ} \mathrm{C}$ and a pressure of $3 \mathrm{bar}$, the measured conversion of $\mathrm{SO}_{2}$ is independent of the water concentration when changing from 2 vol\% of water to 5 vol\% of water. Svachula et al. ${ }^{25}$ also tested the inhibiting effect of water on $\mathrm{SO}_{2}$ oxidation at atmospheric pressure and stated that the conversion of $\mathrm{SO}_{2}$ is independent of water at concentrations above 5 vol\% of water. The experiments presented here, are well in line with the results of Svachula et al., since the concentration of 2 vol\% water at 3 bar corresponds to the same partial pressure as 6 
vol\% at 1 bar. Therefore, based on Fig. 5 the results obtained using 2 vol\% of water at 3 bar and the results obtained using 5 vol\% of water at 1 bar are considered comparable.

\section{3 $\mathrm{SO}_{2}$ Inlet Concentration}

The conversion of $\mathrm{SO}_{2}$ was measured as a function of the inlet concentration of $\mathrm{SO}_{2}$ at a temperature of $350^{\circ} \mathrm{C}$ at 1 and 3 bar for the low-V SCR catalyst. The inlet concentration of $\mathrm{SO}_{2}$ was changed from the standard concentration of approximately $900 \mathrm{ppm}$ to 1400 ppm of $\mathrm{SO}_{2}$ at 1 bar and at 3 bar. At 3 bar an additional experiment was also performed with $400 \mathrm{ppm}$ of $\mathrm{SO}_{2}$. The conversion of $\mathrm{SO}_{2}$ using the different inlet concentrations is shown in Fig. 6.

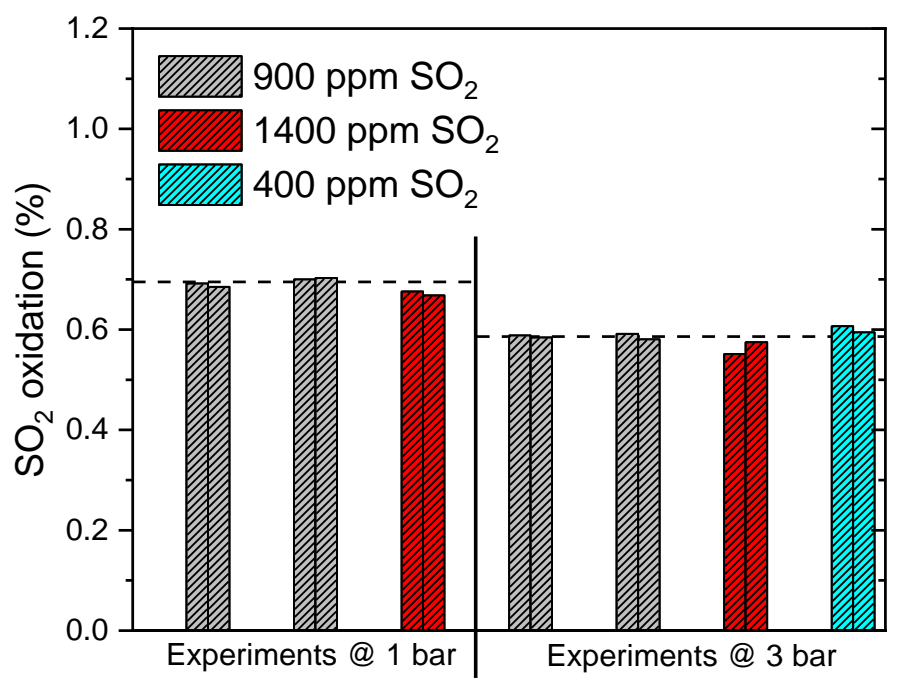

Fig. 6 The conversion of $\mathrm{SO}_{2}$ with varying $\mathrm{SO}_{2}$ inlet concentrations measured at $350^{\circ} \mathrm{C}$ at 1 and 3 bar. The dashed lines indicate the mean of the standard experiment using 900 ppm of $\mathrm{SO}_{2}$

Fig. 6 shows that the conversion of $\mathrm{SO}_{2}$ is independent of the $\mathrm{SO}_{2}$ inlet concentration, indicating a first order reaction as discussed further below. It should be noted that the difference in the conversion of $\mathrm{SO}_{2}$ observed at 1 bar and 3 bar, is due to a higher residence time at 1 bar, as already discussed and shown in Table 1, and hence the conversion of $\mathrm{SO}_{2}$ should not be compared across pressure in Fig. 6.

\section{4 $\mathrm{SO}_{2}$ Kinetic Model}

The extent of external and internal mass transfer limitation is estimated from the Carberry number, and the internal effectiveness factor (See Online Resources 1). On this basis the $\mathrm{SO}_{2}$ oxidation was found to be kinetically controlled, as also reported by other authors ${ }^{17,25,29,32}$, and therefore, the reaction will take place in the full monolith wall. 
A reactor model assuming plug flow of gas through the channels, no transport limitations and an n'th order rate expression was applied when fitting the kinetic parameters, as shown in equation (6). The rate expression on the right hand side of equation (6) assumes a zero reaction order in oxygen which has been reported by other authors under conditions where the oxygen concentration is above 2 vol $\%{ }^{25}$, which is the case for all experiments presented here and typical ship engine out concentrations ${ }^{27}$.

$$
F_{\mathrm{SO}_{2}, 0} \cdot \frac{d X}{d W}=-r_{\mathrm{SO}_{2}}=k \cdot p_{\mathrm{SO}_{2}}{ }^{\alpha} \cdot p_{\mathrm{SO}_{3}}{ }^{\beta}
$$

In equation (6) $\mathrm{FSO}_{2,0}$ is the molar feed rate of $\mathrm{SO}_{2}, W$ is the mass of catalyst and $X$ is the conversion of $\mathrm{SO}_{2}$. The rate constant was fitted using a modified Arrhenius equation, as shown in Equation (7).

$$
k(T)=k\left(T_{r e f}\right) \cdot \exp \left(\frac{-E_{a}}{R} \cdot\left(\frac{1}{T}-\frac{1}{T_{r e f}}\right)\right)
$$

In which $k\left(T_{\text {ref }}\right)$ is the rate constant at a reference temperature, which was chosen at $350^{\circ} \mathrm{C}$, a midpoint in the investigated temperature interval. This way of formulating the rate constant minimizes the correlation between the pre-exponential factor and the activation energy ${ }^{33}$. The four variables, $k\left(T_{\text {ref }}\right), E_{a}, \alpha$, and $\beta$ were fitted by minimization of the residual sum of square (RSS), as given in Equation (8), using the function "Isqcurvefit" in Matlab ${ }^{\circledR}$.

$$
R S S=\sum_{i}\left(y_{\text {calc }}-y_{\text {exp }}\right)^{2}
$$

The goodness of a fitting result is evaluated based on the residual mean square error (RMSE) which is the RSS value divided by the number of data points.

\subsection{Fitting Results}

The first fitting was done for the low V-SCR catalyst where changes in the inlet $\mathrm{SO}_{2}$ concentration were performed at 1 bar and 3 bar, which made it possible to fit both rate constant, activation energy and the reaction orders at each pressure as shown in Table 3.

Table 3 The results of fitting at individual pressures across the low V-SCR catalyst, where changes in the inlet $\mathrm{SO}_{2}$ concentration was performed, see Section 3.3

$\overline{\text { Low V-SCR Catalyst }}$




\begin{tabular}{|c|c|c|c|c|c|}
\hline $\begin{array}{c}\text { Pressure } \\
\text { bar }\end{array}$ & $\begin{array}{c}\mathrm{k}\left(350^{\circ} \mathrm{C}\right) \\
\mathrm{mol} /\left(\mathrm{kg}^{*} \mathrm{~s}^{*} \mathrm{Pan}\right)\end{array}$ & $\begin{array}{c}\mathrm{E}_{\mathrm{a}} \\
\mathrm{kJ} / \mathrm{mol}\end{array}$ & $\alpha$ & $\beta$ & RMSE \\
\hline 1 bar & $0.092 \cdot 10^{-6}$ & 53.2 & 0.77 & 0.14 & $3.45 \cdot 10^{-5}$ \\
\hline 3 bar & $0.092 \cdot 10^{-6}$ & 50.3 & 0.78 & 0.18 & $6.13 \cdot 10^{-5}$ \\
\hline
\end{tabular}

The low RMSE values in Table 3 indicate a good fit. However, the fitting solutions depended on the initial guess, due to too few data points. The solutions shown in Table 4, were the ones giving the lowest RMSE while still keeping similar reference rate constants and activation energies at the two pressures. The results shown in Table $\mathbf{3}$ show that the reaction rate parameters did not significantly change when changing the pressure, and therefore, the datasets were merged into one dataset for each catalyst and refitted as shown in Table 4.

Table 4 Results of fitting the merged data for each catalyst. Red entries are forced and therefore not fitted

\begin{tabular}{ccccc}
\hline \multicolumn{5}{c}{ Low V-SCR Catalyst } \\
\hline $\mathrm{k}\left(350^{\circ} \mathrm{C}\right)$ & $\mathrm{E}_{\mathrm{a}}$ & $\alpha$ & $\beta$ & $\mathrm{RMSE}$ \\
$\mathrm{mol} /\left(\mathrm{kg}^{*} \mathrm{~s}^{*} \mathrm{~Pa}^{\mathrm{n}}\right)$ & $\mathrm{kJ} / \mathrm{mol}$ & & & \\
\hline $0.092 \cdot 10^{-6}$ & 50.7 & 0.78 & 0.16 & $1.05 \cdot 10^{-4}$ \\
$0.040 \cdot 10^{-6}$ & 60.5 & 0.91 & 0 & $1.28 \cdot 10^{-4}$ \\
$0.025 \cdot 10^{-6}$ & 57.2 & 1 & 0 & $1.07 \cdot 10^{-3}$ \\
\hline
\end{tabular}

\begin{tabular}{ccccc}
\hline \multicolumn{5}{c}{ High V-SCR Catalyst } \\
\hline $\begin{array}{c}\mathrm{k}\left(350^{\circ} \mathrm{C}\right) \\
\mathrm{mol} /\left(\mathrm{kg}^{*} \mathrm{~s}^{*} \mathrm{~Pa}^{\mathrm{n}}\right)\end{array}$ & $\mathrm{EJ} / \mathrm{mol}$ & $\alpha$ & $\beta$ & $\mathrm{RMSE}$ \\
\hline $0.040 \cdot 10^{-6}$ & 49.7 & 1.08 & 0.16 & $4.28 \cdot 10^{-3}$ \\
$0.016 \cdot 10^{-6}$ & 59.2 & 1.25 & 0 & $4.41 \cdot 10^{-3}$ \\
$0.053 \cdot 10^{-6}$ & 63.4 & 1 & 0 & $0.545 \cdot 10^{-1}$ \\
\hline
\end{tabular}

The fitting of the merged dataset for the low V-SCR catalyst resulted in solutions that were independent of the initial guess, and as expected the goodness of the fit was poorer as shown by the RMSE values in Table 4 compared to Table 3. Table 4 also shows fitting results for the merged dataset for the high V-SCR catalyst. Entry 1, in Table 4, shows that when all four parameters were fitted, it resulted in a slightly positive value for the reaction order of $\mathrm{SO}_{3}(\beta)$ for both catalysts. Dunn et al. ${ }^{24}$ tested a series of binary catalysts (1-7 wt\% $\mathrm{V}_{2} \mathrm{O}_{5} / \mathrm{TiO}_{2}$ ) and found that the reaction order of $\mathrm{SO}_{2}$ could only be fitted as a first order when a negative first order was assumed for $\mathrm{SO}_{3}$. Dunn et al. observed as high as $10 \% \mathrm{SO}_{2}$ conversion, resulting in an $\mathrm{SO}_{3}$ concentration of around 100 ppm. However, since Dunn et al. performed atmospheric experiments, the partial pressure of $\mathrm{SO}_{3}$ corresponds to about the same value as obtained at elevated pressure in the experiments presented here. A negative first order dependency of $\mathrm{SO}_{3}$ was not found in this work, but rather a value close to zero. Since the reaction order of $\mathrm{SO}_{3}$ was found close to zero it was assumed to be zero and the other three parameters refitted.

Based on a zero order dependency of $\mathrm{SO}_{3}(\beta=0)$, the fitted reaction order of $\mathrm{SO}_{2}(\alpha)$ was close to 1 for the low V-SCR as shown in Table 4 entry 2. Experiments with variation in 
inlet $\mathrm{SO}_{2}$ concentration was only performed using the low V-SCR catalyst, making that dataset better suited for fitting of reaction orders. The small positive reaction order of $\alpha=1.25$, found for the high V-SCR catalyst is considered close to one, since the fractional higher order does not seem physical. Based on these fitting results, the reaction order of $\mathrm{SO}_{2}$ is in general found close to 1 , and hence for practical purposes, a first order dependency can be used, also for increased pressures of up to 4.5 bar. A practical first order dependency was also proposed by Svachula et al. ${ }^{25}$ for atmospheric pressures.

The proposed first order dependency of $\mathrm{SO}_{2}$, and a zero order dependency on $\mathrm{SO}_{3}$, resulted in an activation energy of $57.2 \mathrm{~kJ} / \mathrm{mol}$ and a reference rate constant at $350^{\circ} \mathrm{C}$ of $0.025 \cdot 10^{-6} \mathrm{~mol} /\left(\mathrm{kg}^{*} \mathrm{~s}^{*} \mathrm{~Pa}\right)$ for the low $\mathrm{V}-\mathrm{SCR}$ catalyst and $63.4 \mathrm{~kJ} / \mathrm{mol}$ and a reference rate constant at $350^{\circ} \mathrm{C}$ of $0.053 \cdot 10^{-6} \mathrm{~mol} /\left(\mathrm{kg}^{*} \mathrm{~s}^{*} \mathrm{~Pa}\right)$ for the high V-SCR catalyst. The reference rate constant for the high V-SCR is 2.1 times higher than that for the low V-SCR catalyst. This indicates that the rate of $\mathrm{SO}_{2}$ oxidation scales roughly linearly with the V-content since the high V-SCR catalyst contains 2.5 times more active material ( $3 \mathrm{wt} \%$ vs. 1.2 wt\%). Similar activation energies have also been reported by other authors ${ }^{28,30}$, however, higher activation energies have also been reported, i.e., Beeckman et al. ${ }^{29}$ with an activation energy of $110 \mathrm{~kJ} / \mathrm{mol}$.

In Fig. 7 the measured conversion of $\mathrm{SO}_{2}$ is plotted against that calculated based upon the kinetics assuming first order in $\mathrm{SO}_{2}$ and zero order in $\mathrm{SO}_{3}$ as shown in Table 4.

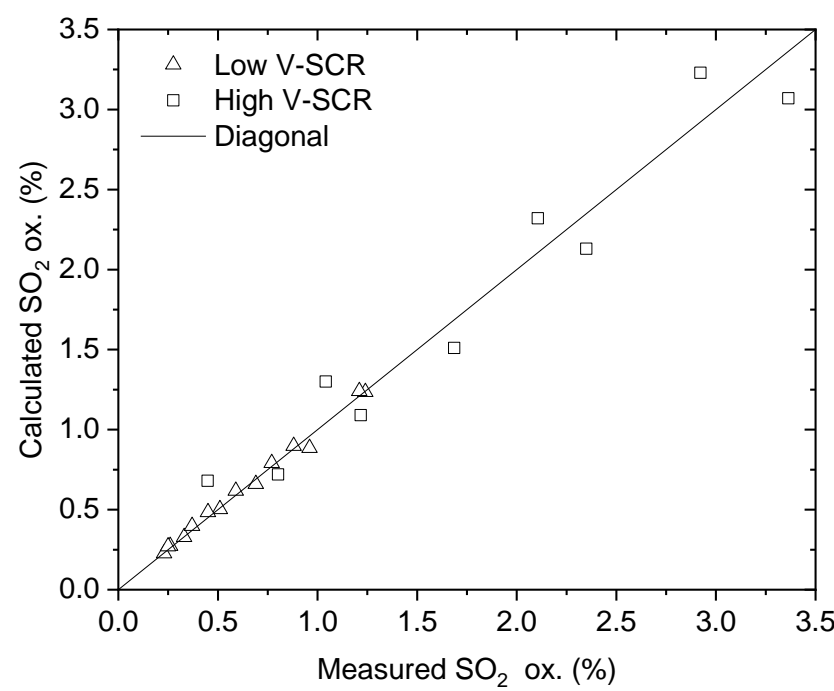

Fig. 7 A parity plot, showing how well the final kinetics fits the measured data. A good fit is indicated by points on the diagonal 
Fig. 7 shows that there is a good agreement between the fitted and measured data for the low V-SCR catalyst. For the high V-SCR catalyst a poorer agreement is observed which was also expected, based on the uncertainty observed in the dataset.

\subsection{Fitted Kinetics Compared to Literature Values}

$\mathrm{SO}_{2}$ oxidation kinetics have been found in the literature, and for comparison, the natural logarithm of the rate of reaction is shown in Fig. 8 together with the kinetics found in this study. Full kinetic expressions are sparse in the literature, so the data shown in Fig. 8 are based on rate plots found in the literature, which were read off as $[X, Y]$ points by use of "plot digitizer ${ }^{34 "}$ and transformed into the same units i.e., $\mathrm{mol} /\left(\mathrm{m}^{3}{ }_{\text {cat }} \cdot \mathrm{s}\right)$. For instance in Beeckman et al. ${ }^{29}$ the first order rate constant is found in units of $\mathrm{cm} / \mathrm{s}$, which are changed based on the supplied catalyst volume specific surface area, $\mathrm{SS}=1.23 \cdot 10^{6} \mathrm{~cm}^{2} / \mathrm{cm}^{329}$, and using first order in $\mathrm{SO}_{2}$ with an initial concentration of 1000 ppm $\mathrm{SO}_{2}$.

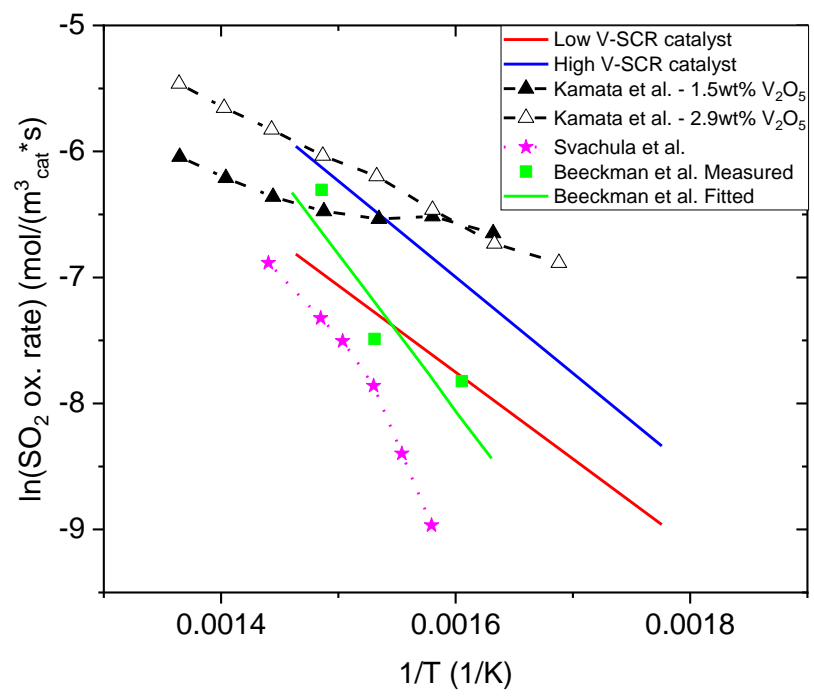

Fig. 8 The rate of $\mathrm{SO}_{2}$ oxidation, based on kinetics fitted to first order in $\mathrm{SO}_{2}$ and zero order in $\mathrm{SO}_{3}$ at $1000 \mathrm{ppm} \mathrm{SO}_{2}$ and compared to kinetics found in the literature by Kamata et al. ${ }^{28}$, Svachula et al. ${ }^{25}$, and Beeckman et al. ${ }^{29}$

Fig. 8 shows that the kinetics found in this study are similar to those found in the literature ${ }^{25,28,29}$. Kamata et al. ${ }^{35}$ studied $\mathrm{SO}_{2}$ oxidation on grounded binary catalysts with various loading of $\mathrm{V}_{2} \mathrm{O}_{5}$ on $\mathrm{TiO}_{2}$ in an atmosphere of 500 ppm $\mathrm{SO}_{2}, 7500 \mathrm{ppm} \mathrm{O}_{2}$, and balance $N_{2}$. The fact that no $W_{3}$ was present in the catalyst and no water in the gas phase compared to the results presented here, would be expected to result in a higher rate, although this is not apparent from Fig. 8. A possible reason could be that Kamata et al. did experiments with a low oxygen concentration, where the rate can be limited by 
the lack of oxygen $\left(\mathrm{O}_{2}<2 \%{ }^{25}\right)$. Kamata et al. observed similar rates at temperatures lower than $600 \mathrm{~K}$ for catalysts with $1.5 \mathrm{wt} \%$ or $2.9 \mathrm{wt} \% \mathrm{~V}_{2} \mathrm{O}_{5}$, which is likely due to difficulties in measuring the very low rate, especially because, Kamata et al. measured the conversion of $\mathrm{SO}_{2}$ by evaluating the consumption of $\mathrm{SO}_{2}$, and not the formation of $\mathrm{SO}_{3}$ directly.

Beeckman et $\mathrm{al}^{29}$ tested a commercial catalyst, with 0.4 wt\% $\mathrm{V}_{2} \mathrm{O}_{5}$ on $\mathrm{TiO}_{2}$ in an

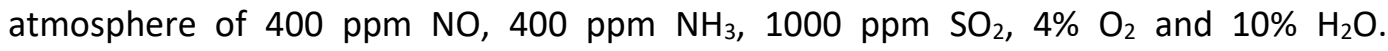
Beeckman et al. do not state whether $\mathrm{WO}_{3}$ is part of the catalyst. However, one could speculate that $\mathrm{WO}_{3}$ (or $\mathrm{MoO}_{3}$ ) is present since it is commonly added to commercial vanadium based $\mathrm{SCR}$ catalyst, to suppress the $\mathrm{SO}_{2}$ oxidation ${ }^{36}$ and suppress the transformation of $\mathrm{TiO}_{2}$, from the high surface area form of anatase to rutile ${ }^{37}$. With the presence of both $\mathrm{NO}$ and $\mathrm{NH}_{3}$ and the possible lack of $\mathrm{WO}_{3}$ and less $\mathrm{V}_{2} \mathrm{O}_{5}$ in the catalyst makes it hard to speculate on whether or not a similar rate should be expected. Ammonia in the gas is reported to decrease the rate of $\mathrm{SO}_{2}$ oxidation ${ }^{25,32}$ and is kinetically modelled as a competitive adsorption on the surface of the catalyst. However, none of the studies comment on the sulfate formation which happens when $\mathrm{NH}_{3}$ and $\mathrm{SO}_{3}$ is present in the gas. Formation of sulfates could decrease the measured conversion of $\mathrm{SO}_{2}$, but not necessarily the $\mathrm{SO}_{2}$ oxidation itself. For instance, Orsenigo et al. ${ }^{17}$ reported a decrease in measured $\mathrm{SO}_{3}$ when ammonia was added to the exhaust gas, however, they also detected a maximum concentration of $\mathrm{SO}_{3}$ after ammonia was should off again, after which the $\mathrm{SO}_{3}$ levels then returned to its original values in a matter of 8 hours. The maximum could be due to decomposition of sulfates. Studies including $\mathrm{NH}_{3}$ and taking into account sulfate formation should be performed.

The rate of $\mathrm{SO}_{2}$ oxidation reported by Svachula et al. ${ }^{25}$ was measured using $1000 \mathrm{ppm}$ $\mathrm{SO}_{2}, 2 \% \mathrm{O}_{2}, 10 \% \mathrm{H}_{2} \mathrm{O}$ and balance $\mathrm{N}_{2}$ on commercial V-SCR catalyst. As with Beeckman et al. the presence of $\mathrm{WO}_{3}$ in the commercial catalyst is not stated, and the $\mathrm{V}_{2} \mathrm{O}_{5}$ concentration is stated to be low, within a possible range of $0.3-2 \mathrm{wt} \% \mathrm{~V}_{2} \mathrm{O}_{5}$ that Svachula et al. investigated. The low $\mathrm{V}_{2} \mathrm{O}_{5}$ concentration, should result in a lower rate of $\mathrm{SO}_{2}$ oxidation compared to the results from this study, which is clear in Fig. 8. Svachula et al. reported a change in activation energy within the investigated temperature interval $\left(T=360-420^{\circ} \mathrm{C}\right)$, and compared it to those typically found for vanadium based sulfuric acid catalyst. However, vanadium present in sulfuric acid catalysts are known to be in the liquid molten state ${ }^{38}$ which is not the case for the vanadium based SCR catalyst, hence the break is unexpected, and not observed for the catalyst used here. 


\section{7 $\mathrm{SO}_{2}$ Oxidation in the presence of $\mathrm{NO}_{\mathrm{x}}$}

$\mathrm{SO}_{2}$ oxidation was also studied across the low V-SCR catalyst with $1000 \mathrm{ppm}$ of $\mathrm{NO}_{\mathrm{x}}$ present in the gas at 1 and 3 bar and an additional experiment was performed with 1000 ppm NO, and 400 ppm $\mathrm{NO}_{2}$ at 3 bar. $\mathrm{NO}_{x}$ was added as pure NO, however, small amounts of the $\mathrm{NO}$ can be oxidized to $\mathrm{NO}_{2}$ before and within the catalyst especially at increased pressure (not measured), and the term "NO ${ }_{x}$ addition" is therefore used. When both $\mathrm{NO}$ and $\mathrm{NO}_{2}$ were added, a $\mathrm{NO}_{2}$ generator was used, in which $\mathrm{NO}$ and air were mixed using an over-stoichiometric ratio of oxygen and allowed to react at room temperature in a long Teflon tube. The $\mathrm{NO}_{2}$ generator is known from previous tests by Haldor Topsøe A/S to result in conversions above $95 \%$ of $\mathrm{NO}$ to $\mathrm{NO}_{2}$. When $400 \mathrm{ppm}$ of $\mathrm{NO}_{2}$ was added, it is under the assumption of $100 \% \mathrm{NO}$ conversion in the $\mathrm{NO}_{2}$ generator. $\mathrm{NO}$, and $\mathrm{NO}_{2}$ are added separately to the hot gas, and subsequently mixed. In SCR experiments not reported here with a similar residence time 1-2 ppm of $\mathrm{NO}_{2}$ was present at atmospheric pressure and 6-8 ppm of $\mathrm{NO}_{2}$ at 3 bar. The oxidation of $\mathrm{NO}$ is believed to follow a second order dependency in NO, hence increasing the NO concentration (by increasing the pressure from 1 to 3 bar), more than doubles the $\mathrm{NO}_{2}$ concentration $^{39}$.

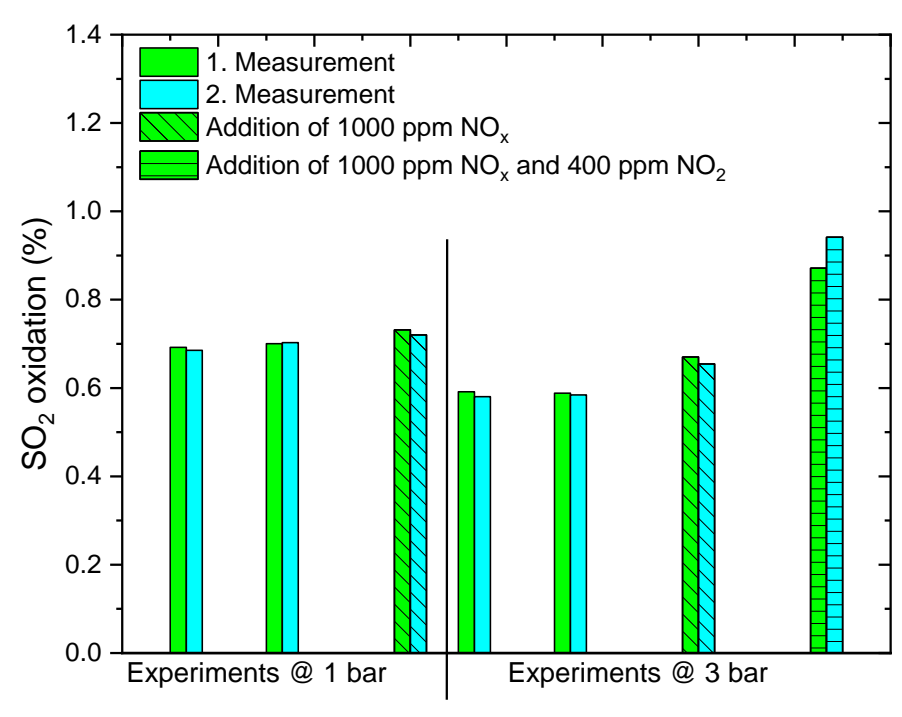

Fig. $9 \mathrm{SO}_{2}$ oxidation measured at $350^{\circ} \mathrm{C}$ at 1 and 3 bar across the low V-SCR catalyst without $\mathrm{NO}_{x}$, with 1000 ppm NOx, and with 400 ppm NO 2 and 1000 ppm NOx. Beside $\mathrm{NO}_{x}$ standard conditions as shown in Table 1 was used

Fig. 9 shows a small increase of $4.5 \%$ in the conversion of $\mathrm{SO}_{2}$ when $1000 \mathrm{ppm}$ of $\mathrm{NO}_{x}$ was added to the gas mixture at 1 bar indicating a small promoting effect of $\mathrm{NO}_{\mathrm{x}}$. However, the small relative increase of $4.5 \%$ compared to the $1.8 \%$ of difference 
between the two repetitions is considered too small to give a definite conclusion. At 3 bar and when 1000 ppm of $\mathrm{NO}_{x}$ was added, the conversion of $\mathrm{SO}_{2}$ increased from $0.59 \%$ to $0.66 \% \mathrm{SO}_{2}$ oxidation, i.e., an increase by $12 \%$, which is expected to be due to a catalyzed reaction between $\mathrm{SO}_{2}$ and $\mathrm{NO}_{2}$ according to reaction (9). To further investigate if the increased oxidation was due to a reaction with $\mathrm{NO}_{2}$, an additional amount of 400 ppm of $\mathrm{NO}_{2}$ was added, which increased the conversion of $\mathrm{SO}_{2}$ with $54 \%$ compared to without $\mathrm{NO}_{x}$, from $0.59 \%$ to a mean of $0.91 \% \mathrm{SO}_{2}$ oxidation.

$$
\mathrm{NO}_{2}+\mathrm{SO}_{2} \rightarrow \mathrm{NO}+\mathrm{SO}_{3}
$$

Measurements performed by Orsenigo et al. ${ }^{17}$, showed that the promoting effect of $\mathrm{NO}_{\mathrm{x}}$ on the conversion of $\mathrm{SO}_{2}$ was only observed when a catalyst was present, indicating that the gas phase reaction is negligible. The lack of gas phase reaction was also confirmed by calculations using a detailed chemical kinetic model of the gas phase reactions ${ }^{40}$ at $400^{\circ} \mathrm{C}, 1 \mathrm{bar}, 1000 \mathrm{ppm} \mathrm{NO}{ }_{2}$ and $3000 \mathrm{ppm} \mathrm{SO}$. Orsenico et al. ${ }^{17}$ suggested that the promoting effect could be explained by an over oxidation of the V-SCR catalyst, however, in this study it is explained by reaction (9) being catalyzed by the V-SCR catalyst, since this reaction thermodynamically should be possible $\left(\Delta G^{\circ}=-35 \frac{\mathrm{kJ}}{\mathrm{mol}}\right)^{41}$. Earlier studies ${ }^{17,25,32}$ have all reported a promoting effect of $\mathrm{NO}_{\mathrm{x}}$ measured at atmospheric pressures. However, in these studies, $\mathrm{NO}_{x}$ and air were mixed at room temperature and subsequently heated together which can cause an increased formation of $\mathrm{NO}_{2}$ since the $\mathrm{NO}$ oxidation in air has a negative activation energy $(\mathrm{Ea} / \mathrm{R}=-530 \pm$ $400 \mathrm{~K}^{39}$ ) and therefore will be limited at increased temperature. This also explains why the addition of $\mathrm{NO}_{x}$ at 1 bar in the experiments presented in this paper only gives a small promoting effect because NO is added directly to the hot $\left(300-400^{\circ} \mathrm{C}\right)$ feed gas, and hence, only at elevated pressure a substantial amount of $\mathrm{NO}_{2}$ is expected.

\section{Conclusion}

The following conclusions can be drawn from this study of $\mathrm{SO}_{2}$ oxidation at pressures up to 4.5 bar across two commercial marine V-SCR catalysts with either 'low' or 'high' vanadium content:

- The oxidation of $\mathrm{SO}_{2}$ is found to be kinetically limited in the temperature interval relevant for SCR operation $\left(300-425^{\circ} \mathrm{C}\right)$. 
- The measured conversion of $\mathrm{SO}_{2}$ into $\mathrm{SO}_{3}$ across the commercial catalysts is of the order $0.2-3 \%$, with no influence of pressure when the residence time was constant. This shows that the kinetics is independent on the pressure in the investigated range.

- The catalyst with the higher vanadium content was more active for $\mathrm{SO}_{2}$ oxidation.

- The kinetics of the reaction was fitted, and the reaction orders were found to be close to one for $\mathrm{SO}_{2}$ and zero for $\mathrm{SO}_{3}$. For practical purposes, it is therefore proposed that the reaction order is approximated by a first order dependency in $\mathrm{SO}_{2}$ and a zero order dependency in $\mathrm{SO}_{3}$ also at pressures up to 4.5 bar.

- The rate of $\mathrm{SO}_{2}$ oxidation was found independent of water concentrations above 2 vol\% at 3 bar, in correspondence with previous findings that the rate is independent of the water concentration above 5 vol\% at 1 bar.

- The fitted kinetics are well in line with those found in the literature measured at atmospheric pressure.

- The rate of $\mathrm{SO}_{2}$ oxidation was clearly promoted by the presence of $\mathrm{NO}_{x}$ at increased pressure, however, at 1 bar the promoting effect was within experimental uncertainty. The promoting effect is explained by a catalyzed redox reaction between $\mathrm{SO}_{2}$ and $\mathrm{NO}_{2}$.

\section{Acknowledgement}

This work is part of the Danish societal partnership, Blue INNOship and partly funded by Innovation Fund Denmark (IFD) under File No: 155-2014-10 and the Danish Maritime Fund. SMC gratefully acknowledge the funding support and the help received from the team at Topsøe $A / S$ while running the experiments at their facilities.

\section{Conflict of Interest}

On behalf of all authors, the corresponding author states that there is no conflict of interest.

\section{Abbreviations}


NOx emission control area

NOx

RMSE

RSS

SCR

SECA

SOx

V-SCR Catalyst

\section{Symbols}

$\alpha$

$\beta$

$E_{a}$

$F_{a .0}$

$\mathrm{G}^{\circ}$

$k\left(T_{\text {ref }}\right)$

$\mathrm{pa}$

Q

SS

$T_{\text {ref }}$

W

$x$

$X_{e}$
Reaction order of $\mathrm{SO}_{2}[]$

Reaction order of $\mathrm{SO}_{3}[]$

Activation Energy [kJ/mol]

Molar feed rate of component a [mol/s]

Gibbs free energy at $25^{\circ} \mathrm{C}$

$\mathrm{SO}_{2}$ rate constant at temperature $\mathrm{T}_{\text {ref }}$

Partial pressure of component a $[\mathrm{Pa}]$

Total volumetric flow rate $\left[\mathrm{m}^{3} / \mathrm{h}\right]$

Specific surface area of catalyst

Reference temperature for $\mathrm{SO}_{2}$ rate expression [K]

Mass of catalyst $[\mathrm{kg}]$

Conversion []

Equilibriums conversion [] 
Yexp
Calculated $\mathrm{SO}_{2}$ conversion

Measured $\mathrm{SO}_{2}$ conversion 


\section{References}

(1) Lamas, M. I.; Rodríguez, C. G. Emissions from Marine Engines and NO x Reduction Methods. J. Marit. Res. 2012, 9 (1), 77-81.

(2) Österman, C.; Magnusson, M. A Systemic Review of Shipboard SCR Installations in Practice. WMU J. Marit. Aff. 2013, 12 (1), 63-85.

(3) Lehtoranta, K.; Vesala, H.; Koponen, P.; Korhonen, S. Selective Catalytic Reduction Operation with Heavy Fuel Oil: NOx , NH3, and Particle Emissions. Environ. Sci. \$|\&\$ Technol. 2015, 49 (7), 47354741.

(4) Corbett, J. J.; Fischbeck, P. Emissions from Ships. Science (80-. ). 1997, 278 (5339), 823-824.

(5) Det Norske Veritas (DNV). Marpol 73/78 Annex VI http://hulpinnood.nl/wpcontent/uploads/2015/03/BIJLAGE3_Marpol-annex-VI.pdf (accessed May 9, 2016).

(6) IMO. IMO MEPC 66/6/15 http://www.worldshipping.org/industry-issues/environment/airemissions/MEPC_66-6-15_-

_Comments_concerning_potential_amendments_to_the_effective__.pdf (accessed Nov 20, 2017).

(7) Bosch, H.; Janssen, F. Preface. Catal. Today 1988, 2 (4), v.

(8) Forzatti, P.; Lietti, L. Recent Advances in DeNOxing Catalysis for Stationary Applications. Heterog. Chem. Rev. 1996, 3 (1), 33-51.

(9) Centi, G.; Perathoner, S. Chapter 1 Introduction: State of the Art in the Development of Catalytic Processes for the Selective Catalytic Reduction of NOx into N2. In Studies in Surface Science and Catalysis; 2007; pp 1-23.

(10) Koebel, M.; Elsener, M.; Madia, G. Recent Advances in the Development of Urea-SCR for Automotive Applications. Sae Tech. Pap. 2001.

(11) Bank, R.; Buchholz, B.; Harndorf, H.; Rabe, R.; Etzien, U. High-Pressure SCR at Large Diesel Engines for Reliable NOx -Reduction and Compliance with IMO Tier III Standards. In CIMAC Congress; 2013.

(12) Magnusson, M.; Fridell, E.; Harelind, H. Improved Low-Temperature Activity for Marine Selective Catalytic Reduction Systems. Proc. Inst. Mech. Eng. Part M J. Eng. Marit. Environ. 2014.

(13) Soikkeli, N.; Lehikoinen, M.; Ronnback, K.-O. Design Aspects of SCR Systems for HFO Fired Marine Diesel Engines. In CIMAC Congress; 2013.

(14) Blakeman, P.; Arnby, K.; Marsh, P.; Newman, C.; Smedler, G. Optimization of an SCR Catalyst System to Meet EUIV Heavy Duty Diesel Legislation. SAE Tech. Pap. 2008, 2 (724).

(15) Walker, A. P.; Blakeman, P. G.; Ilkenhans, T.; Magnusson, B.; Mcdonald, A. C. The Development and In-Field Demonstration of Highly Durable SCR Catalyst Systems Reprinted From : Diesel Exhaust 
Emission Control. SAE Int. 2004-01-1289 2004, No. 724.

(16) Ura, J. a; Girard, J.; Cavataio, G.; Montreuil, C.; Lambert, C. Cold Start Performance and Enhanced Thermal Durability of Vanadium SCR Catalysts. SAE Tech. Pap. Ser. 2009, 1-625.

(17) Orsenigo, C.; Beretta, A.; Forzatti, P.; Svachula, J.; Tronconi, E.; Bregani, F.; Baldacci, A. Theoretical and Experimental Study of the Interaction between NOx Reduction and SO2 Oxidation over DeNOxSCR Catalysts. Catal. Today 1996, 27 (1-2), 15-21.

(18) Burke, J. M.; Johnson, K. L. Ammonium Sulfate and Bisulfate Formation in Air Preheaters (Project Summary); 1982.

(19) Matsuda, S.; Kamo, T.; Kato, A.; Nakajima, F.; Kumura, T.; Kuroda, H. Deposition of Ammonium Bisulfate in the Selective Catalytic Reduction of Nitrogen Oxides with Ammonia. Ind. \$ \&\$ Eng. Chem. Prod. Res. Dev. 1982, 21 (1), 48-52.

(20) Muzio, L.; Bogseth, S.; Himes, R.; Chien, Y.-C.; Dunn-Rankin, D. Ammonium Bisulfate Formation and Reduced Load SCR Operation. Fuel 2017, 206, 180-189.

(21) Thøgersen, J. R.; Slabiak, T.; White, N. Ammonium Bisulphate Inhibition of SCR Catalysts Contents :; Denmark, 2012.

(22) Kröcher, O.; Elsener, M.; Bothien, M.-R.; Dölling, W. Pre-Turbo SCR - Influence of Pressure on NOx Reduction. MTZ Worldw. 2014, 75 (4), 46-51.

(23) Sandelin, K.; Peitz, D. SCR under Pressure - Pre-Turbocharger NOx Abatement for Marine 2-Stroke Diesel Engines. In CIMAC Congress; 2016.

(24) Dunn, J. P.; Koppula, P. R.; G. Stenger, H.; Wachs, I. E. Oxidation of Sulfur Dioxide to Sulfur Trioxide over Supported Vanadia Catalysts. Appl. Catal. B Environ. 1998, 19 (2), 103-117.

(25) Svachula, J.; Alemany, L. J.; Ferlazzo, N.; Forzatti, P.; Tronconi, E.; Bregani, F. Oxidation of Sulfur Dioxide to Sulfur Trioxide over Honeycomb DeNoxing Catalysts. Ind. \$|\&\$ Eng. Chem. Res. 1993, 32 (5), 826-834.

(26) Tronconi, E.; Cavanna, A.; Orsenigo, C.; Forzatti, P. Transient Kinetics of SO2 Oxidation Over SCRDeNO x Monolith Catalysts. Ind. \$|\&\$ Eng. Chem. Res. 1999, 38 (7), 2593-2598.

(27) Magnusson, M.; Fridell, E.; Ingelsten, H. H. The Influence of Sulfur Dioxide and Water on the Performance of a Marine SCR Catalyst. Appl. Catal. B Environ. 2012, 111-112 (145), 20-26.

(28) Kamata, H.; Ohara, H.; Takahashi, K.; Yukimura, A.; Seo, Y. SO2 Oxidation over the V2O5/TiO2 SCR Catalyst. Catal. Letters 2001, 73 (1), 79-83.

(29) Beeckman, J. W.; Hegedus, L. L. Design of Monolith Catalysts for Power Plant NOx Emission Control. Ind. \$|\&\$ Eng. Chem. Res. 1991, 30 (5), 969-978.

(30) Orsenigo, C.; Lietti, L.; Tronconi, E.; Forzatti, P.; Bregani, F. Dynamic Investigation of the Role of the Surface Sulfates in NOx Reduction and SO2 Oxidation over V2O5/WO3/TiO2 Catalysts. Ind. \$|\&\$ 
Eng. Chem. Res. 1998, 37 (6), 2350-2359.

(31) Nielsen, M. T. On the relative importance of SO2 oxidation to high dust SCR DeNOx units http://www.topsoe.com/sites/default/files/topsoe_importance_of_so2_oxidation_to_high_dust_s cr_april_08.ashx_.pdf (accessed Oct 5, 2015).

(32) Tronconi, E.; Beretta, A.; Elmi, A. S.; Vinci, P. L. Da; Malloggi, S.; Baldacci, A. A Complete Model of SCR Monolith Reactors for the Analysis of Interacting NOx Reduction and SO2 Oxidation Reactions. Chem. Eng. Sci. 1994, 49 (24), 4277-4287.

(33) Rawlings, J. B.; Ekerdt, J. G. Chemical Reactor Analysis and Design Fundamentals, 2. Edition.; Nob Hill Pub, 2002.

(34) Plot Digitizer http://plotdigitizer.sourceforge.net/ (accessed Jan 24, 2018).

(35) Kamasamudram, K.; Currier, N.; Szailer, T.; Yezerets, A. Why Cu- and Fe-Zeolite SCR Catalysts Behave Differently At Low Temperatures. SAE Int. J. Fuels Lubr. 2010, 3 (1), 664-672.

(36) Sazonova, N. N.; Tsykoza, L. T.; Simakov, A. V.; Barannik, G. B.; Ismagilov, Z. R. Relationship between Sulfur Dioxide Oxidation and Selective Catalytic NO Reduction by Ammonia on V2O5-TiO2 Catalysts Doped with WO3 and Nb2O5. React. Kinet. \$|\&\$ Catal. Lett. 1994, 52 (1), 101-106.

(37) Gabrielsson, P.; Pedersen, H. G. Flue Gas From Staionary Sources. In Handbook of heterogeneous catalysis.; Ertl, G., Knözinger, H., Schüth, F., Weitkamp, J., Eds.; Wiley-VCH, 2008; pp 2345-2385.

(38) Ivanov, A. A.; Balzhinimaev, B. S. New Data on Kinetics and Reaction Mechanism for SO2 Oxidation over Vanadium Catalysts. React. Kinet. Catal. Lett. 1987, 35 (1-2), 413-424.

(39) Tsukahara, H.; Ishida, T.; Mayumi, M. Gas-Phase Oxidation of Nitric Oxide: Chemical Kinetics and Rate Constant. Nitric Oxide 1999, 3 (3), 191-198.

(40) Glarborg, P. Hidden Interactions-Trace Species Governing Combustion and Emissions. Proc. Combust. Inst. 2007, 31 (1), 77-98.

(41) NIST database https://www.nist.gov/ (accessed Dec 22, 2017). 